\title{
Cow-Calf Response to Stocking Rates, Graz- ing Systems, and Winter Supplementation at the Texas Experimental Ranch
}

\author{
R.K. HEITSCHMIDT, M.M. KOTHMANN, AND W.J. RAWLINS
}

\author{
Abstract
}

Cow-calf performance from 1960 through 1978 was contrasted between three grazing treatments at the Texas Experimental Ranch. Grazing treatments were yearlong continuous stocked at annual rates averaging 5.1 and $7.6 \mathrm{ha} / \mathrm{cow}$ and a 4 -pasture, 3-herd deferred rotation system stocked at an annual rate averaging $\mathbf{7 . 2}$ ha/cow. Averaged across three weighing periods, cows in the deferred rotation treatment averaged $447 \mathrm{~kg}$ while weight of cows in the heavily and moderately stocked continuous trentments averaged 427 and $438 \mathrm{~kg}$, respectively. Calf weaning weights averaged 204,212 , and $217 \mathrm{~kg}$ for the heavy continuous, moderate continuous, and Merrill rotation treatments, respectively. Production/cow averaged 182, 189, and $202 \mathrm{~kg}$ while production/ha averaged $35.9,25.2$, and $27.8 \mathrm{~kg}$, respectively, for the heavy continuous, moderate continuous, and deferred rotation treatments. Cows fed winter supplement were significantly heavier in early spring and summer than nonsupplemented cows with no significant differences in weights by late summer. Supplemented cows weaned calves averaging $214 \mathrm{~kg}$ as compared to $208 \mathrm{~kg}$ for calves weaned from nonsupplemented cows. Winter supplementation significantly increased production in the heavily stocked treatment but not in either of the moderately stocked treatments. Numerous statistically significant interactions accompanied the significant main effects, and the biological significance of each was examined.

The Texas Experimental Ranch was created in 1959 to provide researchers with the necessary facilities to evaluate the longterm responses of both livestock and vegetation to various grazing systems and rates of stocking. Kothmann et al. $(1970,1971)$ concluded from a thorough analysis of the cow-calf performance data collected at the ranch from 1961 through 1968 that no economic advantages were apparent from either yearlong continuous grazing at a light rate of stocking ( $11.5 \mathrm{ha} / \mathrm{AU})$ or from a 2-pasture, 1-herd deferred rotation system (Joubert 1958) stocked at a moderate rate ( 8.4 ha/ $\mathrm{AU})$ when contrasted to continuous grazing and a 4-pasture, 3-herd deferred rotation system (Merrill 1954) stocked at a moderate rate $(8.0 \mathrm{ha} / \mathrm{AU})$. In addition, it was concluded that feeding cottonseed meal $(41 \% \mathrm{CP})$ as a winter supplement at a rate exceeding $0.68 \mathrm{~kg} /$ day was not economically justifiable in any of the grazing treatments. Thus, in 1969 only three grazing treatments that had been initiated in 1960 were continued. These treatments were yearlong continuous grazing at moderate and heavy rates of stocking and the 4-pasture, 3-herd deferred rotation system.

\footnotetext{
Authors are associate professor, Department of Range Science, Texas A\&M University Research and Extension Center, Box 1658, Vernon 76384; professor, Department of Range Sciences, Texas A\&M University, College Station 77843; and former research associate, Department of Range Science, Texas A\&M University Research and Extension Center, Box 1658, Vernon 76384.

Report is published with approval of the Director, Tex. Agr. Exp. Sta. as TA 15813

-Authors express appreciation to Swenson Land and Cattle Co. Swen R. Swenson Cattle Co., Texas Experimental Ranch Committee and the many people who have worked on this project through the past 20 years. Appreciation is also expressed to Dr. R.J. Freund, associate director, Institute of Statistics, Texas A\&M University, for his assistance in the statistical anlyses included in this paper.

Manuscript received March 31, 1980.
}

Two additional systems were evaluated at the ranch from 1969 through 1973. These were a modified 2-pasture, 1-herd system and a 3-pasture, 2-herd system, neither of which proved as productive as the 4-pasture, 3-herd system (Kothmann and Mathis 1974). Both of these systems were terminated in the fall of 1973 and a 8-pasture, 1-herd short duration grazing system was initiated. Evaluation of this system was continued through 1978 (Heitschmidt and Rawlins 1980). Thus, only the yearlong continuous grazing treatments stocked at the moderate and heavy rates of stocking and the 4-pasture, 3-herd deferred rotation treatment have been continued without interruption. The objective of this manuscript is to summarize the cow and calf performance data from these three treatments from 1960 through 1978.

\section{Location and Climate}

\section{Study Area and Methods}

The Texas Experimental Ranch consists of approximately 2900 ha of native range located $\left(99^{\circ} 14^{\prime} \mathrm{W}, 33^{\circ} 20^{\prime} \mathrm{N}\right)$ in the northern portion of the Rollings Plains of Texas. Weather data collected since 1961 (unpublished) indicates a highly variable, semiarid, continental climate of mild, dry winters; warm, wet springs and falls; and hot summers. Maximum daily temperatures range from an average of $13^{\circ} \mathrm{C}$ in January to $36^{\circ} \mathrm{C}$ in July with mean minimums ranging from $-3^{\circ}$ to $21^{\circ} \mathrm{C}$ in January and July, respectively. Mean annual precipitation is $690 \mathrm{~mm}$ with approximately $70 \%$ received from April through September. The frost-free growing season, averaging 233 days, extends from March to November.

\section{Grazing Treatment}

Grazing treatments studied were: yearlong continuous grazing stocked at an average rate of $5.1 \mathrm{ha} /$ cow/year (heavy continuous); yearlong continous grazing stocked at an average rate of 7.6 ha/cow/year (moderate continuous); and a 4-pasture, 3-herd deferred rotation system stocked at an average rate of $7.2 \mathrm{ha} / \mathrm{co}-$ $w /$ year (Merrill rotation). Herd movement in the Merrill rotation sequentially provided each pasture with a 4-month rest period following a l-year grazing period (Merrill 1954).

Average annual stocking rates were gradually increased from 1960 to 1978 within each treatment (Fig. 1). This was necessary to maintain relatively constant grazing pressures as the range condition of each pasture improved, particularly in those pastures stocked at the moderate rate. Minor adjustments in rates of stocking within a year were occasionally required in all treatment pastures during periods of extended drought. A major adjustment was required in the heavy continuous treatment from October 1974 to June 1975 (Fig. 1) because of severe drought. By 1978 the two heavy continuous herds consisted of 50 cows each, the moderate continuous herds consisted of 37 cows each, and the three herds in the Merrill rotation treatment consisted of 24 cows each.

Type of supplement, feeding rate, dates fed, and treatment herds fed varied between years but never between treatments within a year (Table 1). To eliminate the effect of differences between 


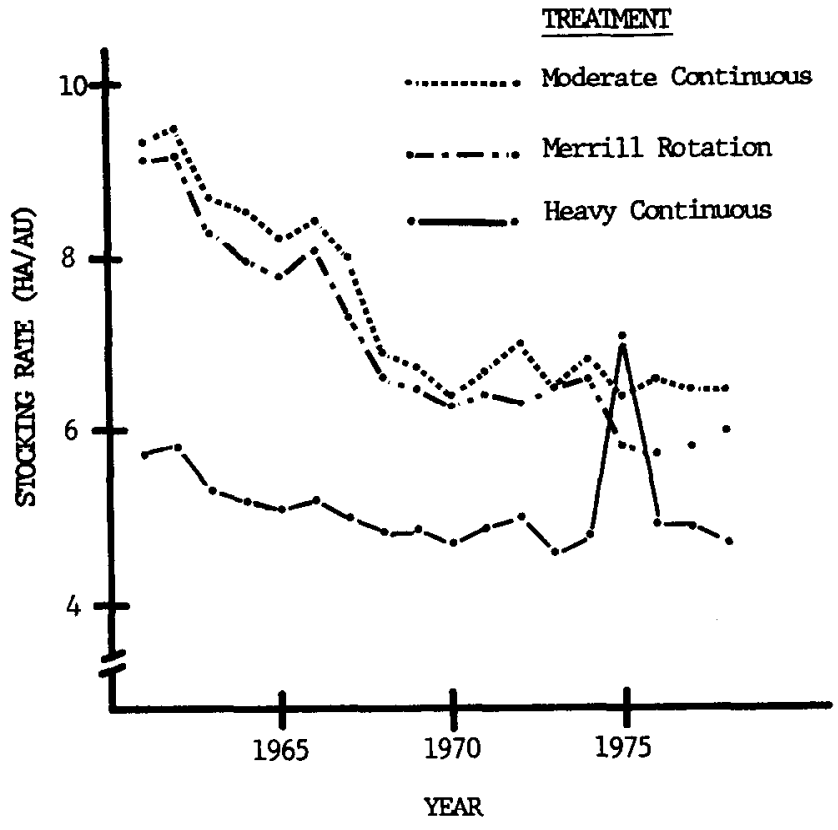

Fig. 1. Annual stocking rate for the grazing treatments at the Texas Experimental Ranch from 1961 through 1978.

pastures, the two herds in each of the yearlong continuous treatments were switched in October of each year. Thus, the same herd was supplemented each year but it was only fed in the same pasture every other year.

Because of the feeding regime in 1975 and 1976, the 1976 data were not included in the analyses. The data from $M$ herd in 1977 and 1978 were also excluded from the analyses because the lack of supplement in 1976 seriously impaired the breeding performance of that herd in subsequent years.

\section{Livestock Management}

During the 18 years, three herds of Hereford cows were utilized in the study (Table 1). The breeding season was from March 15 to June 15 for Herd I (1960 through 1968); from March 1 to June 1 for Herd II (1969 through 1974); and, from January 1 to March 1 for Herd III (1975 through 1978). Fertility-tested Hereford bulls were randomly allotted each year at a ratio not exceeding 20 cows to one bull. Both cows and calves were weighed when calves were approximately 90,160 , and 230 days old. Calves were weaned at 8 to 10 months of age

Within 2 months following weaning of calves, cows in each treatment were culled if unhealthy and/or if they had not weaned a calf for two consecutive years. Few cows were culled for the latter reason, regardless of treatment. Neither replacement cows nor their calves were considered valid test animals until they had been in their respective treatment for 1 year. This restriction eliminated the use of the 1960,1969 and 1975 data in these analyses.

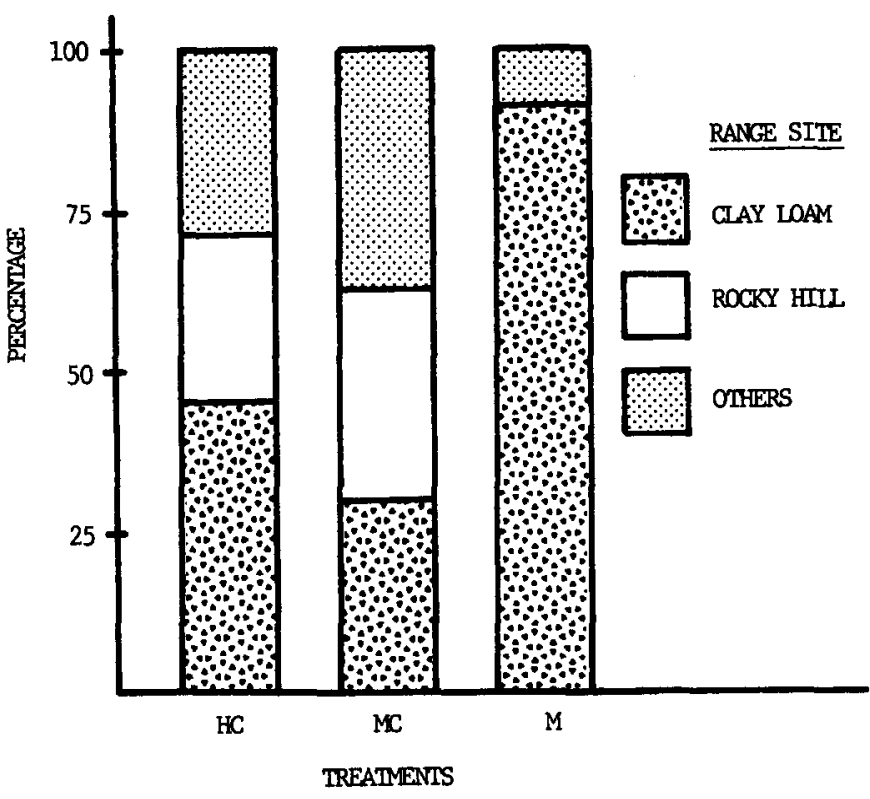

Fig. 2. Range site composition (\%) of pastures included in heavy continuous (HC), moderate continuous (MC), and Merrill rotation $(M R)$ grazing treatments at Texas Experimental Ranch.

\section{Vegetation}

The two principal range sites in the treatment pastures were the Clay Loam and Rocky Hills (Fig. 2). Other common range sites were Shallow, Shallow Clay, Clay Flat, Redland, Deep Redland, and Loamy Bottomland.

The Clay Loam site is generally located on gentle slopes of $0-3 \%$. The clay and clay loam soils a re moderately permeable with high water holding capacity. Dominant soil series are Valera clay, Leeray clay and Throck silty clay. Principal climax species are sideoats grama [Bouteloua curtipendula (Michx.) Torr.], vine mesquite (Panicum obtusum H.B.K.), Arizona cottontop [Digitaria californica (Benth.) Henr.] and silver bluestem [Bothriochloa saccharoides (Swartz) Rydb.]. Estimated annual forage production for this site when in excellent condition ranges from 1700 to 3400 $\mathrm{kg} / \mathrm{ha}$ (SCS 1979).

The Rocky Hills site is located on steeper slopes ranging from 3 to $12 \%$. The clay soils are often shallow but moderately permeable with high water-holding capacities. Valera stoney clay and Owens stoney clay are the dominant soil series of this site. Climax vegetation is dominanted by sideoats grama, little bluestem [Schizachyrium scoparium, (Michx.) Nash.], big bluestem (Andropogon gerardi Vitman), Indiangrass [Sorghastrum nutans (L.) Nash], and switchgrass (Panicum virgatum $\mathrm{L}$.). Estimated forage production for this site when in excellent condition ranges from 1300 to 2700 $\mathrm{kg} / \mathrm{ha}$ (SCS 1979).

Standing crop data were collected in the treatment pastures

Table 1. Supplemental feeding regime in three grazing treatments at Texas Experimental Ranch from 1960 through 1978.

\begin{tabular}{|c|c|c|c|c|c|}
\hline \multirow[b]{2}{*}{ Herd } & \multirow[b]{2}{*}{ Year } & \multicolumn{4}{|c|}{ Supplemental Feed } \\
\hline & & Type & Ratel & Feeding period & Treatment herds fed ${ }^{2}$ \\
\hline I & $1960-1968$ & cottonseed cake $(41 \%)^{3}$ & 0.68 & Dec. 15-Mar. 15 & $\mathrm{~A}, \mathbf{B}, \mathbf{K}, \mathbf{L}, \mathbf{M}$ \\
\hline 11 & $1969-1974$ & cottonseed cake $(41 \%)$ & 0.68 & Dec. 15-Mar. 15 & $\mathrm{~A}, \mathrm{~B}, \mathrm{~K}$ \\
\hline \multirow[t]{2}{*}{ III } & 1975 & range cubes $(20 \%)$ & 0.91 & Dec. 1 -Mar. 31 & $\mathbf{A}, \mathbf{B}, \mathbf{K}$ \\
\hline & & range cubes $(20 \%)$ & 1.81 & Dec. 1 -Mar. 31 & $\mathrm{~F}, \mathrm{D}, \mathrm{L}, \mathrm{M}$ \\
\hline \multirow[t]{2}{*}{ III } & 1976 & range cubes $(20 \%)$ & 0.91 & Dec.15-Mar.15 & $\mathrm{A}, \mathrm{B}, \mathrm{K}$ \\
\hline & & cottonweed cake $(41 \%)$ & 0.45 & Dec. 15-Mar. 15 & $\mathrm{~F}, \mathrm{D}, \mathrm{L}$ \\
\hline III & $1977-1978$ & range cubes $(12 \%)$ & 1.36 & Dec. 1 -Feb. 28 & $\mathrm{~A}, \mathbf{B}, \mathbf{K}, \mathbf{M}$ \\
\hline
\end{tabular}

${ }^{1} \mathrm{~kg} /$ day fed three days/week

${ }^{2}$ Grazing treatment herds are: $A \& F=$ heavy continuous, $B \& D=$ moderate continuous; $K, L, \& M=$ Merrill rotation

3 Percent crude protein. 
Table 2. Total and error degress of freedom (d.f.) and $F$-values for various least squares analysis of variance models utilized in statistical analyses.

\begin{tabular}{|c|c|c|c|c|c|c|c|c|c|}
\hline \multirow[b]{3}{*}{ Source of variation } & \multicolumn{9}{|c|}{ Dependent variable } \\
\hline & \multirow{2}{*}{$\begin{array}{l}\text { Cow } \\
\text { weights } 1\end{array}$} & \multirow{2}{*}{$\begin{array}{l}\text { Calf weaning } \\
\text { weights }\end{array}$} & \multirow{2}{*}{$\begin{array}{l}\text { Calf } \\
\text { weights }\end{array}$} & \multirow{2}{*}{$\begin{array}{l}\text { Calf weight } \\
\text { gains }\end{array}$} & \multirow{2}{*}{$\begin{array}{l}\text { Conception } \\
\text { rates }\end{array}$} & \multirow{2}{*}{$\begin{array}{l}\text { Calf crop } \\
\text { weaned }\end{array}$} & \multirow{2}{*}{$\begin{array}{l}\text { Calf death } \\
\text { losses }\end{array}$} & \multicolumn{2}{|c|}{ Production } \\
\hline & & & & & & & & $\mathrm{kg} /$ cow & $\mathrm{kg} / \mathrm{ha}$ \\
\hline Year & $40.0^{* *}$ & $58.0^{* *}$ & $137.0^{* *}$ & $63.9 * *$ & $4.8^{* *}$ & $3.5^{* *}$ & 1.4 & $12.2^{* *}$ & $7.9 * *$ \\
\hline Treatment & $28.5^{* *}$ & $22.6^{* *}$ & $80.6^{* *}$ & 1.5 & 2.3 & 3.0 & 1.0 & $7.6^{* *}$ & $115.0^{* *}$ \\
\hline Y X T & $2.7^{* *}$ & $2.4^{* * *}$ & $5.2^{* *}$ & $2.3^{* *}$ & $1.9^{*}$ & $2.4^{* *}$ & 1.1 & $1.8^{*}$ & $2.3^{* *}$ \\
\hline Supplement & $28.2^{* *}$ & $14.7^{* * *}$ & $65.9 * *$ & 0.8 & 0.3 & 0.2 & 1.2 & 1.2 & 3.1 \\
\hline $\mathbf{Y} \times \mathbf{S}$ & 1.6 & $1.8^{*}$ & $4.8^{* *}$ & $1.8^{*}$ & $2.8^{* *}$ & $3.3^{* *}$ & 1.1 & 1.6 & $2.4^{*}$ \\
\hline$T \times S$ & 1.0 & 0.5 & 2.1 & 0.1 & 2.5 & $3.6^{*}$ & 1.2 & 2.3 & $3.5^{*}$ \\
\hline Weighing period (WP) & $223.3 * *$ & - & $13016.8^{* *}$ & $426.2 * *$ & - & - & - & - & - \\
\hline Y X WP & $4.8 * *$ & - & $24.7^{* *}$ & $60.6^{* *}$ & - & - & - & - & - \\
\hline$T \times W P$ & $3.6^{* *}$ & - & 0.9 & 0.1 & - & - & - & - & - \\
\hline$S \times W P$ & $6.2^{* *}$ & - & 0.8 & $7.6^{* *}$ & - & - & - & - & - \\
\hline Calf sex & - & $73.9^{* *}$ & $135.1^{* *}$ & $48.8^{* *}$ & - & - & - & - & 一 \\
\hline Model & $17.4 * *$ & $17.2^{*}$ & $272.8 * *$ & $28.0^{* *}$ & $2.6^{* *}$ & $2.6^{* *}$ & 1.2 & $5.2^{* *}$ & $7.6^{* *}$ \\
\hline Total d.f. freedom & 273 & 206 & 618 & 412 & 103 & 103 & 103 & 103 & 103 \\
\hline Error d.f. freedom & 187 & 126 & 500 & 313 & 41 & 41 & 41 & 41 & 41 \\
\hline
\end{tabular}

during the summers of 1970 and 1972 on the Deep Upland and Rolling Hill range sites (Kothmann et al. 1978) both of which have since been reclassified as Clay Loam. Total standing crop averaged $1484 \mathrm{~kg} / \mathrm{ha}$ in the heavy continuous treatment pastures, 2178 $\mathrm{kg} / \mathrm{ha}$ in the moderate continuous treatment pastures, and 1977 $\mathrm{kg} / \mathrm{ha}$ in the Merrill rotation pastures. Total standing crop averaged $3145 \mathrm{~kg} / \mathrm{ha}$ inside exclosures that were established in 1959. Differences in total standing crop were primarily the result of differences in both livestock utilization and species composition. The dominant specie in the heavy continuous pastures was buffalograss (Buchloe dactyloides (Nutt.) Engelm.) as opposed to midgrass dominants of sideoats grama and Texas wintergrass (Stipa leucotricha Trin. and Rupr.) in the moderately stocked pastures and the exclosures.

\section{Data Set and Statistical Analyses}

The data set consisted of annual herd means. Parameters analyzed were: cow and calf weights for three weigh dates; calf weaning weights; production/cow; production/ha; percentage of cows pregnant; percent calf crop weaned; and percent calf death loss. Production/cow was calculated by multiplying calf weaning weight adjusted for sex of calf by number of tester cows weaning a calf and then dividing by total number of tester cows. Production/ha was then determined by dividing production/cow by rate of stocking (ha/cow). Percent of cows pregnant was determined by palpation. Percent calf death loss was calculated by subtracting percent calves weaned from percent cows pregnant.

Data were analyzed utilizing least squares analysis of variance, analysis of covariance and linear regression procedures. The fixed variable analysis of variance models was applied as a factorial design without treatment replications. Tukey $Q$ values were utilized for mean separation where appropriate (Snedecor and Cochran 1967). All mean values reported are least square estimates which generally deviated less than $2 \%$ from the raw data means.

Since weigh dates for both cows and calves were dependent upon age of calf, the 1977 and 1978 cow weights were analysed separately from the 1961 through 1974 weights. This was necessary since the calving season in 1977 and 1978 began approximately 60 calendar days earlier than during the period from 1961 to 1974.

\section{Results}

\section{Cow Weights}

Cow weight analyses for 1961 through 1974 indicated all main effects were significant with several significant interactions (Table 2). Averaged across all treatments and years, cow weights averaged $410 \mathrm{~kg}$ in early April, $454 \mathrm{~kg}$ in mid-June, and $447 \mathrm{~kg}$ in early September. The treatment by weighing period interaction revealed that cows in the heavy continuous treatment were significantly lighter in both April and June than cows in the moderate continuous and Merrill rotation treatments (Table 3). By September, no significant difference in cow weights was noted between the two continuous treatments but cows in the Merrill rotation treatment were significantly heavier than cows in either continuous treatment. Examination of weight changes over time within a treatment (Table 3) indicated all cows gained a significant a mount of weight during the spring. No gains were apparent during the summer, with the cows in the moderate continuous treatment losing a significant amount of weight.

Table 3. Mean weight of cows (kg) on three weigh dates for three grazing treatments at Texas Experimental Ranch from 1961 through 1974. Treatments were heavy continuous (HC), moderate continuous (MC), and Merrill rotation (MR).

\begin{tabular}{lccc}
\hline & & & Treatment \\
\cline { 2 - 4 } Weighing period & HC & MC & MR \\
\hline 1 & $394_{\mathrm{a}} \mathrm{l}$ & $412_{\mathrm{b}}$ & $425_{\mathrm{c}}$ \\
2 & $445_{\mathrm{c}}$ & $458_{\mathrm{d}}$ & $460_{\mathrm{d}}$ \\
3 & $440_{\mathrm{c}}$ & $444_{\mathrm{c}}$ & $457_{\mathrm{d}}$ \\
\hline
\end{tabular}

'Means within same row or column followed by same letter are not significantly different at $\boldsymbol{P}<0.05$.

The supplement by weighing period interaction indicated that supplemented cows were significantly heavier in early April and June than nonsupplemented cows with no differences noted by September (Table 4). The lack of significant weight differences in September was because supplemented cows lost weight during the summer while the weight of the nonsupplemented cows did not change. The lack of significant year by supplement and treatment by supplement interactions (Table 2) suggested response to supplement was similar across years and treatments.

The year by weighing period interaction emphasized annual variation in weights across seasons. Averaged across the three

Table 4. Mean weight of winter supplemented and nonsupplemented cows (kg) from three grazing treatments on three weigh dates at Texas Experimental Ranch from 1961 through 1974.

\begin{tabular}{lcc}
\hline & \multicolumn{2}{c}{ Supplemented } \\
\cline { 2 - 3 } Weighing period & Yes & No \\
\hline 1 & $421_{\mathrm{a}}{ }^{\prime}$ & $400_{\mathrm{b}}$ \\
2 & $46 \mathrm{l}_{\mathrm{b}}$ & $447_{\mathrm{c}}$ \\
3 & $449_{\mathrm{c}}$ & $445_{\mathrm{c}}$ \\
\hline
\end{tabular}

Means within same row or column followed by same letter are not significantly different at $P<0.05$. 
Table 5. Annual means for three grazing treatments for varlous production parameters at Texas Experimental Ranch from 1961 through 1978 . Row means are significantly different at $P<0.05$ if differences exceed $Q$-value.

\begin{tabular}{lrrrrrrrrrrrrrrrr}
\hline & \multicolumn{10}{c}{ Year } \\
\cline { 2 - 12 } Parameter & 1961 & 1962 & 1963 & 1964 & 1965 & 1966 & 1967 & 1968 & 1970 & 1971 & 1972 & 1973 & 1974 & 1977 & 1978 & value \\
\hline Cow weight & 427 & 432 & 438 & 421 & 480 & 455 & 469 & 440 & 414 & 403 & 454 & 429 & 417 & 4351 & 4051 & 18 \\
Calf weaning weight (kg) & 231 & 219 & 230 & 211 & 230 & 217 & 237 & 216 & 190 & 204 & 223 & 218 & 196 & 183 & 161 & 12 \\
Calf weaning weight (kg) & 217 & 218 & 200 & 206 & 227 & 217 & 235 & 212 & 211 & 203 & 222 & 215 & 202 & 202 & 182 & 10 \\
Conception rates & 99 & 96 & 99 & 96 & 92 & 98 & 98 & 94 & 84 & 97 & 96 & 95 & 94 & 90 & 97 & 10 \\
Production/cow (kg) & 219 & 196 & 221 & 194 & 204 & 201 & 233 & 203 & 151 & 190 & 201 & 191 & 168 & 158 & 143 & 33 \\
Production/ha (kg) & 27.7 & 24.7 & 30.2 & 27.6 & 29.4 & 28.1 & 34.7 & 33.4 & 25.6 & 32.0 & 33.2 & 32.4 & 28.3 & 28.1 & 25.5 & 5.5 \\
\hline
\end{tabular}

Not included in mean separation.

${ }^{2}$ Actual weight.

${ }^{3}$ Weight adjusted to average age of 236 days

treatments, cows gained a significant amount of weight from early April to June in all years except 1971. The response in 1971 was attributed to a lack of forage resulting from a very dry spring. Total precipitation from January to June in 1971 was $92 \mathrm{~mm}$ as compared to a 20 year average of $251 \mathrm{~mm}$. Likewise, significant weight losses occurred in 8 years from June to September while significant gains occurred in 3 years. Basically, gains were recorded in those years when spring precipitation was either below normal or summer precipitation was above normal.

The year by treatment interaction (Table 2) resulted primarily from annual variations in the magnitude of difference between treatments. Cows in the Merrill rotation treatment were either significantly heavier every year than cows in the moderate and heavy continuous treatments or their weights were not significantly different from the heaviest cows. Similarly, cows in the heavy continuous treatment were either significantly lighter than the cows in the moderate continuous and Merrill rotation treatments every year or their weights were not significantly different from the lightest.

Analyses of the cow weights for 1977 and 1978 reflected basically the same weight responses as established from the 1961 through 1974 analyses. Cows averaged $436 \mathrm{~kg}$ in 1977 while in 1978 they averaged $405 \mathrm{~kg}$. Heaviest cows were in the Merrill rotation (429 $\mathrm{kg}$ ) and lightest in the heavy continuous $(416 \mathrm{~kg})$. Supplementation increased average weights $10 \mathrm{~kg}$. The weighing period effect was quite similar in that cows were lightest in April $(402 \mathrm{~kg})$, heaviest in June ( $445 \mathrm{~kg}$ ) with a nonsignificant loss of weight in August to 440 kg. February weights averaged $395 \mathrm{~kg}$.

The cow weight analyses emphasized the close relationship between cow weights and quantity and/or quality of available forage. Year (Table 5) and weighing period effects were directly related to annual and seasonal variations in quantity and quality of available forage, which are closely related to amount and seasonal distribution of precipitation (Heitschmidt et al. 1982a, 1982b). Treatment effects (Table 6) were related primarily to differences between treatment pastures in vegetative composition as it affects quantity and quality of available forage. Characteristically, the

Table 6. Treatment means for various production parameters at Texas Experimental Ranch from 1961 through 1978. Grazing treatments were heavy continuous (HC), moderate continuous (MC) and Merrill rotation (MR).

\begin{tabular}{lccc}
\hline \hline & \multicolumn{3}{c}{ Treatment } \\
\cline { 2 - 4 } Parameter & HC & MC & MR \\
\hline Cow weight (kg)' & $427_{\mathrm{a}^{2}}$ & $438_{\mathrm{b}}$ & $.447_{\mathrm{c}}$ \\
Calf weaning weight (kg) & $204_{\mathrm{a}}$ & $212_{\mathrm{b}}$ & $2177_{\mathrm{c}}$ \\
Calf weaning weight (kg) & $207_{\mathrm{a}}$ & $212_{\mathrm{b}}$ & $215_{\mathrm{b}}$ \\
Conception rates (\%) & $94_{\mathrm{a}}$ & $96_{\mathrm{a}}$ & $96_{\mathrm{a}}$ \\
Production/cow (kg) & $182_{\mathrm{a}}$ & $189_{\mathrm{ab}}$ & $202_{\mathrm{b}}$ \\
Production/ha (kg) & $35.9_{\mathrm{a}}$ & $25.2_{\mathrm{b}}$ & $27.8_{\mathrm{c}}$ \\
\hline
\end{tabular}

'Does not include 1977 and 1978 data.

2Row means followed by same letter are not significantly different at $P<0.05$. ${ }^{3}$ Actual weight.

4Weight adjusted to average age of 236 days. heavy continuous pastures were dominated by shortgrasses with minimal amounts of Texas wintergrass present while the moderate continuous and Merrill rotation pastures were dominated by midgrasses with considerable amounts of Texas wintergrass present (Kothmann et al. 1978). Because of the shortgrasses, actual as well as potential forage production in the heavily stocked pastures was always less than in the moderately stocked pastures. This reduced forage production, along with the greater utilization of forage resulting from the greater number of livestock present, reduced the quantity of reserve forage present in the heavily stocked pastures relative to the moderately stocked pastures. Thus, when adverse vegetative growing conditions were encountered, quantity of forage became limiting sooner in the heavily stocked pastures than in the moderately stocked pastures.

Quantity of Texas wintergrass present was assumed to be an important factor affecting winter cow weights. Texas wintergrass is a cool-season midgrass capable of making substantial vegetative growth during the fall and winter if adequate precipitation has been received. Thus, the availability of Texas wintergrass can dramatically alter the quality of the winter diet of livestock in this region. Its absence in the heavily stocked pastures presumably reduced overall quality of diet selected.

\section{Calf Weights}

Significant year (Table 5), treatment (Table 6), supplement, and sex of calf effects were revealed from the calf weaning weight (third weight) analyses (Table 2). Two interactions were significant: year by treatment and year by supplement. The year by treatment interaction resulted primarily from changes between years in the magnitude of treatment differences in calf weaning weights. Weaning weights of calves in the heavy continuous treatment in all years were either the lightest or were not significantly different from the lightest. In contrast, weaning weights of calves in the Merrill rotation treatment were either the heaviest or were not significantly different from the heaviest in 14 out of the 15 years. Calves weaned in the moderate continuous treatment were heaviest in 3 years but only significantly heavier than calves in the Merrill rotation in 1968. In 12 years, calves in the moderate continuous treatment were not significantly heavier than calves in the heavy continuous treatment.

The year by supplement interaction was primarily the result of annual variations in magnitude of differences between weaning weights. In seven of the 15 years, supplemented cows weaned calves significantly heavier than nonsupplemented while in only 1 year were calves from nonsupplemented cows significantly heavier than those from supplemented cows. That year was 1961, when the average age of calves weaned from the nonsupplemented cows was 260 days as compared to 243 days for calves weaned from the supplemented cows.

Averaged across years and supplement and corrected for sex of calf, weaning weight of calves in the Merrill rotation treatment averaged $13 \mathrm{~kg}$ more than for calves in the heavy continuous treatment and $5 \mathrm{~kg}$ more than for calves in the moderate continuous treatment (Table 6). Calves weaned from cows fed winter supplement averaged $214 \mathrm{~kg}$ while calves weaned from nonsupple- 
mented cows averaged $208 \mathrm{~kg}$. Average weaning weight of steers was $217 \mathrm{~kg}$ as compared to $206 \mathrm{~kg}$ for heifers.

To contrast differences in weaning weights between years, weights were adjusted for age of calf. The analysis of covariance indicated that age of calf was a significant covariate and that the main and interaction effects that were significant in the analysis of variance (Table 2) were also significant in the analysis of covariance. But differences between years and treatments in calf weaning weights diminished when adjusted for age of calves (Tables 5 and 6). Annual differences were related to differences in amount and distribution of precipitation as discussed in the cow weight. The highly significant correlation $(r=0.77, P<0.01)$ that was established between average cow weights and adjusted calf weaning weights emphasized this relationship. Treatment differences diminished with adjustments for age of calf (Table 4) since calves in the heavy continuous treatment averaged 233.8 days old on the final weigh date while calves in the moderate continuous and Merrill rotation treatments averaged 235.6 and 238.2 days, respectively. Since the difference between the weaning weights of calves in the Merrill rotation and moderate continuous treatments became nonsignificant after weights were adjusted for age of calf (Table 6), a slight delay in breeding was probably the principal reason for differences in calf weaning weights between the two moderately stocked treatments.

Although a delay in breeding and subsequently in calving was apparently a major treatment effect in the heavy continuous treatment, it was not the only factor altering calf weaning weights. Circumstantial evidence of treatment differences in calf birth weights was revealed from the analysis of variance of the calf weights across the three weigh dates. These analyses revealed that all main effects were significant as well as numerous interaction effects (Table 2). But only the weighing period effects were considered biologically important since all other effects were based on the weight of calves averaged across the three weighing periods. The lack of a significant treatment by weighing period effect was most important in that it indicated that the calves in the heavy continuous treatment were significantly lighter on all weigh dates than calves in the two moderately stocked treatments (Table 7). Also it indicated that calves in the moderate continuous treatment were significantly lighter than those in the Merrill rotation treatment on all weigh dates. But when calf weights were adjusted for age, no significant differences were noted between the weight of calves in the moderate continuous and Merrill rotation treatments although weights in the heavy continuous treatment remained significantly lighter. Thus, it is assumed that birth weights of calves in the heavy continuous treatment were significantly lighter than in the moderately stocked treatments since weights were significantly lighter on the first weigh date even after adjusting for differences in birth dates.

Weight gains from the first weigh date to weaning did not differ significantly between treatments (Table 2), although a slight difference was apparent. Unadjusted gains were 120,121 , and $124 \mathrm{~kg}$, respectively, for calves in the heavy continuous, moderate continuous, and Merrill rotation treatments (Table 7). The significant year by treatment, year by supplement, and year by weighing period interaction effects were all related to minor differences in gains between years. The supplement by weighing period interaction

Table 7. Mean weight of calves (kg) on three weigh dates for three grazing treatments at Texas Experimental Ranch from 1961 through 1978. Treatments were heavy continuous (HC), moderate continuous (MC) and Merrill rotation (MR).

\begin{tabular}{lccc}
\hline & & Treatment & \\
\cline { 2 - 4 } Weighing period & HC & MC & MR \\
\hline 1 & $84 '$ & 91 & 93 \\
2 & 150 & 157 & 161 \\
3 & 204 & 212 & 217 \\
\hline
\end{tabular}

${ }^{1}$ All means are significantly different at $P<0.05$. resulted from a significant difference in gains between the first and second weigh dates. Average weight gain of calves from supplemented cows was $2.2 \mathrm{~kg}$ more than that of calves from nonsupplemented cows. Differences in gains between the second and third weigh dates were nonsignificant.

In summary, the calf weight analyses suggested that the heaviest calves were weaned from the Merrill rotation treatment for the three basic reasons: they were older, they were apparently slightly heavier at birth, and they made slightly faster gains. Although individually these effects were not significant, when contrasted among grazing treatments, the accumulative effects were significant.

\section{Conception Rates}

Analysis of variance of conception rates revealed significant year effects, year by treatment interaction effects, and year by supplement interaction effects (Table 2). The year by treatment interaction resulted from the grazing treatment effects that occurred in 1969 when the cows were being bred for the 1970 calf crop. Conception rate in the heavy continuous treatment averaged $66 \%$. This was significantly less than the $87 \%$ conception rate in the moderate continuous treatment and the $92 \%$ in the Merrill rotation. The reason for the reduced rate of conception in the heavy continuous treatment was related to a heavy infestation of annual broomweed (Xanthocephalum spp.) during the summer of 1968. Presumably, this effect was two-fold. First, the broomweed canopy reduced forage production during the growing season. Then the canopy of standing dead broomweed impeded livestock grazing during the fall, winter and spring following the heavy infestation (Kothmann and Rittenhouse 1980).

The year by supplement interaction was also in part related to the 1970 results. Conception rates during the spring of 1969 in the nonsupplemented herds were $50 \%, 82 \%$, and $88 \%$ in the heavy continuous, moderate continuous, and Merrill rotation treatments, respectively. Winter supplementation increased conception rates to $83 \%, 95 \%$, and $100 \%$ for these same treatments. Thus, an obvious interaction existed between the effects of grazing treatment and winter supplementation during the heavy infestation of broomweed.

In addition to 1970 , significant differences did occur between rates of conception in supplemented and nonsupplemented herd in 1965 and 1968. In 1965, rate of conception in the supplemented herds averaged $95 \%$ as compared to $84 \%$ in the nonsupplemented herds. In 1968, the supplemented herds averaged $92 \%$ and the nonsupplemented $100 \%$. No biological significance could be attributed to the effect of winter supplementation on rate of conception in either of these 2 years.

\section{Weaned Calf Crop}

Percentage of cows weaning calves varied significantly between years (Table 5) but not between treatments regardless of supplement (Table 6) or between supplemented and nonsupplemented herds regardless of treatment (Table 2). Because of the relationship between conception rates and calf crop, the interaction effects were closely related to the effects observed in the rate of conception analyses. However, a major difference between the conception rate and calf crop weaned analyses did occur in that the treatment by supplement interaction effect was significant in the calf crop weaned analyses (Table 2). Although there were no significant differences between supplemented or nonsupplemented herds when averaged across treatments, supplementation in the heavy continuous treatment did significantly increase percentage of cows weaning a calf (Table 8).

To evaluate possible differences in calf losses resulting from abortion, death, or possibly an incorrect pregnancy test, an analysis of variance was run on differences between percentage of cows bred and percentage of cows weaning calves. All main effects and interactions were nonsignificant (Table 2), indicating that grazing treatment had no statistically significant effect on calf survival. Thus, it was apparent that the significant treatment by supplement 
Table 8. A verage percent of supplemented and nonsupplemented cows weaning calves from three grazing treatments at Texas Experimental Ranch from 1961 through 1978 . Grazing treatments were heavy continuous (HC), moderate continuous (MC), and Merrill rotation (MR).

\begin{tabular}{lccc}
\hline & \multicolumn{3}{c}{ Treatment } \\
\cline { 2 - 4 } Supplemented & $\mathrm{HC}$ & $\mathrm{MC}$ & $\mathrm{MR}$ \\
\hline NO & $86.0_{\mathrm{a}}{ }^{1}$ & $87.9_{\mathrm{a}}$ & $88.8_{\mathrm{a}}$ \\
YES & $90.8_{\mathrm{b}}$ & $90.5_{\mathrm{ab}}$ & $92.7_{\mathrm{ab}}$ \\
\hline
\end{tabular}

IMeans within same row or column followed by same letter are not significantly diferent at $P<0.05$.

interaction effect on calf crop weaned was a cumulative effect of conception rate and calf survival.

\section{Production}

Production/cow varied significantly between years and treatments with a significant year by treatment interaction (Table 2). A large portion of the year effect was attributed to differences in calf weaning weights which resulted from differences in age of calf at weaning (Table 5). Treatment means reflected basic effects (Table 6) but the year by treatment interaction indicated some variation among years in treatment response. In only 4 years were the differences between treatment means significant. In each of these years, greatest production/cow was recorded in the Merrill rotation treatment while in 3 of these years, lowest production/cow was in the heavy continuous treatment. Over the entire 15 years, greatest production/cow occurred in the Merrill rotation treatment in 10 years, while in 4 years greatest production/cow occurred in the moderate continuous treatment.

Production/ha varied significantly among years (Table 5) and treatments (Table 6) with a significant year by treatment interaction (Table 2). The year by treatment interaction was primarily the result of variations in the magnitude of difference between treatment means within any given year. For example, production/ha in the heavy continuous treatment was significantly greater than in the moderate continuous treatment 13 out of the 15 years with a nonsignificant difference in 1970 and 1978 . The nonsignificant difference in 1970 was directly related to the annual broomweed infestation of 1968 , which significantly reduced the calf crop weaned in the heavy continuous treatment. Differences in 1978 were not significant because calves were lighter in all treatments than in previous years (Table 5). Thus, differences between treatments in production/ha were necessarily smaller than in previous years.

The significant year by supplement interaction resulted primarily from annual variations in the magnitude of differences in production/ha between supplemented and nonsupplemented herds. Mean separation indicated no significant differences between supplemented and nonsupplemented herds in any year except 1970. In 1970 , production/ ha in the supplemented herds averaged $30.5 \mathrm{~kg}$ while averaging $21.9 \mathrm{~kg}$ in the nonsupplemented herds. These differences were primarily related to differences in calf crop weaned.

The treatment by supplement interaction indicated that supplementation significantly increased production/ha in the heavy continuous treatment (Table 9) while no effect was noted in the moderate continuous and Merrill rotation treatments. These data are related to the interaction effect of treatment and supplement on weaned calf crop (Table 8).

\section{Discussion and Conclusion}

The quantitative effects of increasing rates of stocking on livestock production have been well documented (Vallentine 1978). As rate of stocking is increased, production/animal unit slowly declines and production/unit area of land increases until rate of stocking exceeds carrying capacity. At that point, production/animal unit rapidly declines with a subsequent decline in production/unit area. Basically, the data from the heavily and
Table 9. Mean production/ha (kg) for winter supplemented and nonsupplemented grazing treatments at Texas Experimental Ranch from 1961 through 1978. Grazing treatments were heavy continuous (HC), moderate continuous (MC), and Merrill rotation (MR).

\begin{tabular}{lccc}
\hline & \multicolumn{3}{c}{ Treatment } \\
\cline { 2 - 4 } Supplemented & HC & MC & MR \\
\hline NO & $34.1_{1} \mathrm{a}^{1}$ & $25.3_{\mathrm{b}}$ & $27.6_{\mathrm{bc}}$ \\
YES & $37.6_{\mathrm{d}}$ & $25 . \mathrm{l}_{\mathrm{b}}$ & $28.0_{\mathrm{c}}$ \\
\hline
\end{tabular}

'Means within same row or column followed by same letter are not significantly different at $P<0.05$.

moderately stocked continuous treatments in this study support this generalization with regards to the effect of stocking rate on livestock production. Since 1961, the heavier rate of stocking has evidently been near that required to maximize livestock production/ha and net economic returns/ha (Whitson et al. 1982). But this basic conclusion is based entirely upon longterm averages. Close examination of annual variation in net incomes suggests that income stability in the heavy continuous treatment has declined since 1961 and that the need for winter supplementation has become increasingly important to reduce income variability and economic risk (Whitson et al. 1982).

The primary reason for the reduced stability of livestock production and thus income can be related to the changes that have occurred in species composition on the vegetation at the heavier rate of stocking. The classic ecological shift is composition from midgrass dominants to shortgrasses has occurred in these pastures (Kothmann et al. 1978). This shift in species composition has reduced forage production and prevented the accumulation of sufficient forage reserves to sustain the cattle during adverse periods of growth such as 1975. The probability of an economic disaster will continue to increase as these longterm effects of heavy stocking rates become more apparent on the forage resource.

Similarly, the interaction effects of treatment and supplement can also be related to changes in species composition. The shift in composition from midgrasses to shortgrasses has reduced the abundance of Texas wintergrass in the heavy continuous pastures (Kothmann et al. 1978). Because of the high nutritional value of Texas wintergrass during winters, livestock response to winter supplement was directly related to the abundance of Texas wintergrass in any given treatment pasture. The presence of Texas wintergrass reduced the need for winter supplement in the moderately stocked pastures except during extended periods of winter drought, abundant snow fall or heavy infestations of annual broomweed.

The effects of the Merrill rotation system on livestock production are not as easily identified as the effects of rate of stocking because of differences between treatment pastures in potential forage production resulting from differences in range site composition. It is impossible to emphatically conclude that the heavier calf weaning weights and greater production/cow were strictly grazing treatment effects. However, we personally believe that a major portion of these treatment differences were directly attributable to the Merrill rotation grazing system and not to differences in potential forage production among pastures. Since 1960 a gradual improvement in range condition in these four pastures has been apparent with a shift in species composition on the Clay Loam range site towards the midgrass dominants of sideoats grama and Texas wintergrass (Kothmann et al. 1978). The ultimate effect of this range improvement has been to stabilize annual income and decrease economic risk (Whitson et al. 1982). We expect the average differences in livestock production observed between grazing treatments from 1961 through 1978 to remain relatively constant over the next 20 years, assuming no severe drought is encountered. However, we expect the variation in production among years to increase in the heavy continuous treatment and to decrease in the moderately stocked treatments, particularly in the Merrill rotation treatment. We forward this basic hypothesis because we believe 
that the duration of these trials has been of sufficient length of time that an equilibrium has been established between the forage resource and each grazing treatment.

Considerable controversy exists as to the utility of various grazing systems as management tools for improving livestock production (Driscoll 1967, Heady 1969, Launchbaugh et al. 1978, Gammon 1978, Pieper et al. 1978). Gammon (1978) concluded from a thorough review of past research that "there is sufficient evidence from experiments of long duration to indicate that pasture deteriortion can usually be expected under continuous grazing, even at moderate stocking rates, and that stability can be facilitated by a variety of rotational systems." We suggest that the livestock performance data from this study, coupled with the economic analyses (Whitson et al. 1982) and the trends in vegetation response (Kothmann et al. 1978) support this generalization.

\section{Literature Cited}

Driscoll, R.S. 1967. Managing public rangelands: Effective livestock grazing practices and systems for national forests and national grasslands. USDA AlB 315.

Gammon, D.M. 1978. A review of experiments comparing systems of grazing management on natural pastures. Proc. Grass. Soc. S. Afr. 13:75-82.

Heady, H.F. 1969. Continuous vs. specialized grazing systems: A review and application to the California annual type. J. Range Manage. 14:182193.

Heitschmidt, R.K., D.L. Price, R.A. Gordon, and J.R. Frasure. 1982a. Short duration grazing at the Texas Experimental Ranch. II. Effect on aboveground net primary production and seasonal growth dynamics. J. Range Manage. (In Press.)

Heitschmidt, R.K. Gordon, and J.S. Bluntzer. 1982b. Short duration grazing at the Texas Experimental Ranch. III. Effects on forage quality. J. Range Manage. (In Press).

Heitschmidt, R.K., and W.J. Rawlins. 1980. Cow-calf performance as influenced by grazing systems and stocking rates. Tex. Agr. Exp. Sta. PR 3665. p. 20.
Joubert, J.G.V. 1958. Two-camp system for southwest Africa. Farming in S. Afr. 34:33-34

Kothmann, M.M., and G.W. Mathis. 1974. Calf production from ten management systems. Proc. West. Sec. Amer. Soc. Anim. Sci. 25:185188 .

Kothmann, M.M., G.W. Mathis, P.T. Marion, and W.J. Waldrip. 1970. Livestock production and economic returns from grazing treatments at the Texas Experimental Ranch. Tex. Agr. Exp. Sta. Bull. 1100. 39 p.

Kothmann, M.M., G.W. Mathis, and W.J. Waldrip. 1971. Cow-calf response to stocking rates and grazing systems on native range. J. Range Manage. 24:100-105.

Kothmann, M.M., W.J. Waldrip, and G.W. Mathis. 1978. Rangeland vegetation of the Texas Rolling Plains: response to grazing management and weather. In: Proc. First Internat. Range. Cong., Soc. Range Manage. Denver, Colo. p. 606-609.

Kothmann, M.M., and I..R. Rittenhouse. 1980. Texas broomweed reduces calf production. Tex. Agr. Exp. Sta. PR 3665. p. 54.

Launchbaugh, J.L., C.E. Ownsby, F.L. Schwartz, and L.R. Corah. 1978. Grazing management to meet nutritional and functional needs of livestock. In: Proc. First. Internat. Range. Cong., Soc. Range Manage. Denver, Colo. p. 541-546.

Merrill, Leo B. 1954. A variation of deferred rotation grazing for use under southwest range conditions. J. Range Manage. 7:152-154.

Pieper, R.D., G.B. Donart, E.E. Parker, and J.D. Wallace. 1978. Livestock and vegetational response to continuous and 4-pasture, 1-herd grazing systems in New Mexico. In: Proc. First Int. Range. Congr., Soc. Range Manage.. Denver, Colo. p. 560-562.

Snedecor, G.W., and W.C. Cochran. 1967. Statistical methods. 6th ed. lowa State Univ. Press. Ames. $593 \mathrm{p}$.

Soil Conservation Service. 1979. Field office technical guide. Sect. Il E. Native grazing lands. USDA. Abilene, Tex.

Vallentine, John F. (Ed.). 1978. U.S.-Canadian range management, 19351977: A selected bibliography on ranges, pastures, wildlife, livestock and ranching. Oryx Press. Phoenix, Ariz. 337 p.

Whitson, R.E., R.K. Heitschmidt, M.M. Kothmann, and G.K. Lundgren. 1982. The impact of grazing systems on the magnitude and stability of ranch income. J. Range Manage.(In Press).

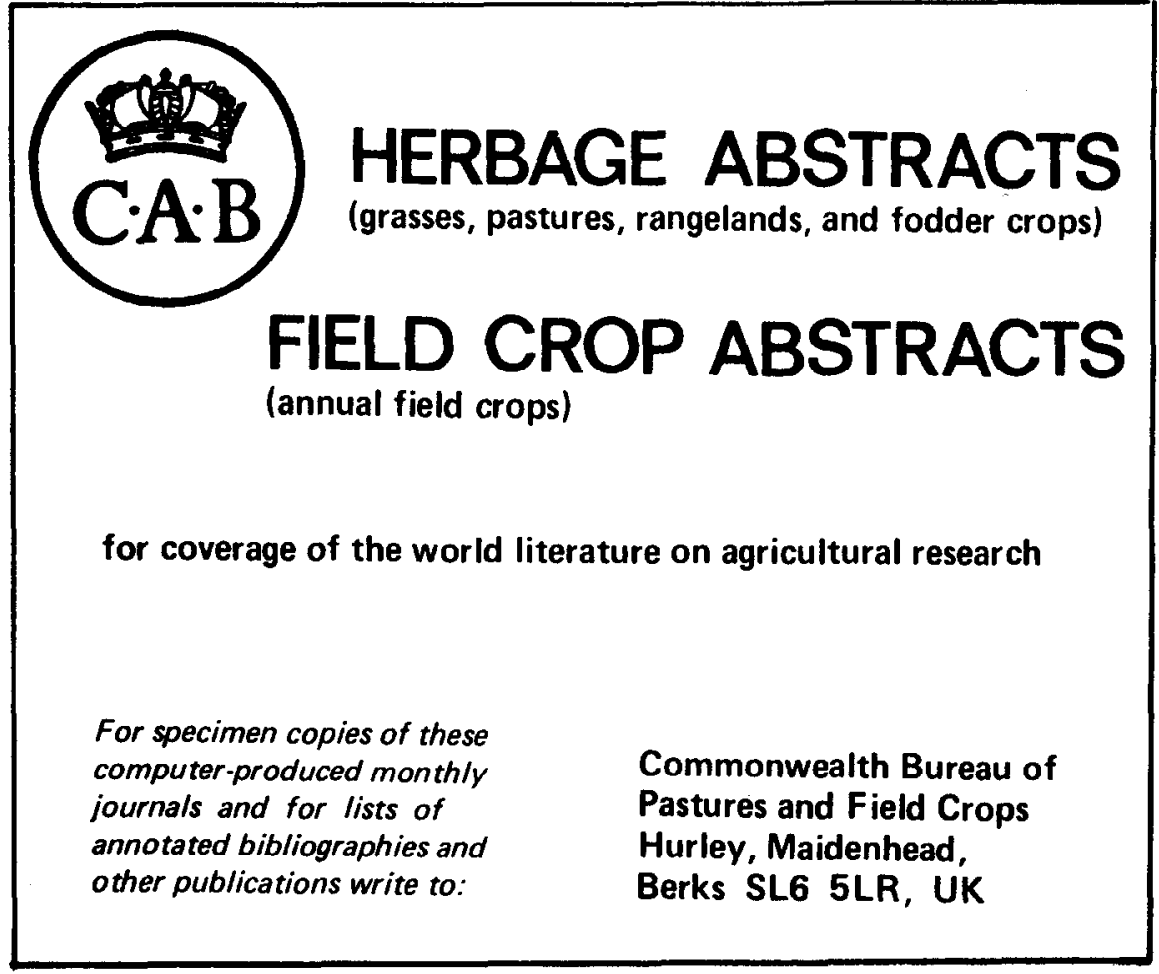

